\title{
Identification and Characterization of Virulence Factor of Several Indonesian Xanthomonas oryzae pv. oryzae
}

\author{
FATIMAH $^{1 *}$, APON ZAENAL MUSTOPA $^{2}$, AND IQBAL KUSNANDARSYAH ${ }^{1}$ \\ 'Indonesian Center for Agricultural Biotechnology and Genetic Resources Research and Development (ICABIOGRAD) \\ Jl. Tentara Pelajar No.3A Cimanggu, Bogor 16111, Indonesia; \\ ${ }^{2}$ Research Center for Biotechnology, Indonesian Institute of Sciences (LIPI) \\ Jalan Raya Bogor Km 46. Cibinong, Bogor 16911, Indonesia
}

\begin{abstract}
Xanthomonas oryzae pv. oryzae (Xoo) is the bacterial causative agent of leaf blight in rice (Oryza sativa L.), the most serious bacterial disease of rice in many rice growing areas worldwide. This study aimed to identify and characterize several virulence factors of seven Xoo isolates from Yogyakarta, West Java, and West Sumatera. The identification of Xoo using 16S rRNA confirmed high homology to Xanthomonas oryzae pv. oryzae PXO99 ${ }^{A}$ and revealed three groups. The first group was Xoo93229, the second group containing Xoo1110, Xoo1122, Xoo1130, Xoo7624 and Xoo8024 as the same cluster with PXO99 ${ }^{A}$ and the third group was KACC10331 and MAFF311018. The amounts of exopolysaccharide (EPS) and cellulase produced were varying depending on the Xoo isolates. The EPS were produced more by isolate Xoo1130, Xoo1122 and Xoo8024. All tested isolates revealed similar cellulase activity except for isolate Xoo8024. The pathogenicity assay among the Xoo isolate showed that all tested isolates were virulent except Xoo7624. The in planta assay revealed that the tested isolates have multiplied and continued increasing the population size except for Xoo1110 and Xoo7624. High yield of EPS, cellulase activity, more virulence, and increasing population size revealed from isolate Xoo1130 and Xoo1122.
\end{abstract}

Key words: Xanthomonas oryzae pv. oryzae, 16 rRNA, virulence factor

Xanthomonas oryzae pv. oryzae (Xoo) merupakan bakteri penyebab penyakit hawar daun padi (Oryza sativa L.) dan merupakan penyakit yang serius di daerah pertanaman padi. Penelitian ini bertujuan untuk mengidentifikasi, mengkarakterisasi dan mengukur aktivitas fenotipe beberapa faktor virulen pada tujuh isolat bakteri Xoo yang diisolasi dari Yogyakarta, Jawa Barat, dan Sumatera Barat. Identifikasi bakteri Xoo menggunakan 16S rRNA diperoleh homologi yang tinggi dengan Xanthomonas oryzae pv. oryzae $\mathrm{PXO} 99^{\AA}$ dan hasil pengelompokan didapatkan tiga grup. Pada grup pertama adalah bakteri Xoo93229, grup kedua adalah bakteri Xoo1110, Xoo1122, Xoo1130, Xoo7624 dan Xoo8024 bersama PXO99 dan pada grup ketiga adalah KACC10331 dan MAFF311018. Besarnya eksopolisakarida (EPS) dan faktor virulen lainnya bervariasi bergantung pada isolat yang digunakan. EPS pada isolat Xoo1130, Xoo1122 dan Xoo8024 diproduksi lebih banyak. Aktivitas cellulase memberikan hasil yang sama pada semua isolat kecuali pada isolat Xoo8024. Uji patogenisitas dan in planta menunjukkan bahwa enam isolat yang diujikan adalah virulen kecuali Xoo7624 kurang virulen pada varietas IR24, peningkatan jumlah populasi bakteri pada semua isolat kecuali pada isolat Xoo1110 dan Xoo7624. Isolat Xoo1130 dan Xoo1122 memberikan nilai yang tinggi pada produksi EPS, aktivitas cellulase, virulensi, dan jumlah populasi bakteri.

Kata kunci : Xanthomonas oryzae pv. oryzae, 16 rRNA, faktor virulensi

Bacterial leaf blight (BLB) caused by Xanthomonas oryzae pv. oryzae (Xoo) is the most devastating bacterial disease of rice production worldwide. Xoo in the fourth position of top 10 bacterial plant pathogen after Pseudomonas syringae, Ralstonia solanacearum and Agrobacterium tumefacient (Mansfield et al. 2012). Xoo infects the rice leaf typically through hydathodes at the leaf tip, broken trichomes, leaf margins and wounds in the

*Corresponding author; Phone: +62-251-8337975, Fax: +62-251-8338820; email: fatimahsuw@gmail.com leaves or roots, multiplies in the intercellular spaces and enters into xylem vessels (Ou 1985; Nozue et al. 2011). After sufficient multiplication in the intercellular spaces of the underlying epitheme, the bacteria enter the xylem and spread in the vascular system (Mew et al. 1993; Liu et al. 2006).

Xоo produces a range of virulence factors, including EPS, extracellular enzymes, and type III effectors (Liu et al. 2014). EPS can play a critical role in facilitating adhesion of bacteria to the host surface during initial stages of plantpathogen interactions and disease development (Subramoni et al. 2006). Cell- 
wall degrading enzymes, such as cellulases, pectinases, xylanases and proteases, are secreted by plant pathogens cells to break down the components of host cell walls and may play a crucial role in virulence and bacterial nutrition (Temujin et al. 2011). Many xanthomonads require a type III secretion system (T3SS) for pathogenicity on plant hosts, and the requirement reflects the utilization of $\mathrm{T} 3$ effectors to mediate the processes of pathogen adaptation to specific host tissues, species and genotypes (Buttner and He 2009; White et al. 2009; Verdier et al.2012).

This study aimed to identify and characterize several virulence factors of seven Xoo from Indonesia and provided new insight towards Indonesian Xoo isolates as general feature of for the development of effective disease control methods.

\section{MATERIALS AND METHODS}

Identification of $X$. oryzae pv oryzae using $16 \mathrm{~S}$ rRNA. Genomic DNA of Xoo was extracted from $5 \mathrm{ml}$ NB cultures grown overnight. The bacterial cells were pelleted and lysed in $650 \mu$ Lextraction buffer $(100 \mathrm{mM}$ Tris $\mathrm{pH}$ 8, $100 \mathrm{mM}$ EDTA, $250 \mathrm{mM} \mathrm{NaCl}, 15 \%$ SDS (w/v), $1 \%$ PVP-40 (w/v) at $65^{\circ} \mathrm{C}$ for 30 minutes. DNA was isolated using a modified method with $100 \mu \mathrm{L}$ of 5 $\mathrm{M}$ potassium acetate and precipitated with isopropanol (George et al. 1997).

For $16 \mathrm{~S}$ rDNA sequencing, primers $8 \mathrm{~F}$ (5'AGAGTTTGATCATGGCTCAG-3' and 15R (5'AAGGAGGTGATCCAACCGCA-3') were used to amplify the full length of bacterial 16s rDNA (Chao et al. 2008). Each $25 \mu 1$ PCR mixture contained $10 \mathrm{mM}$ Tris- $\mathrm{HCl}$ ( $\mathrm{pH} 8.3$ ), $50 \mathrm{mM} \mathrm{KCl}, 1.5 \mathrm{mM} \mathrm{MgCl}_{2}, 200 \mu \mathrm{M}$ of each dNTP, 400nM of each primer, $1 \mathrm{U}$ of Taq polymerase, and $10 \mathrm{ng}$ of the DNA template. The PCR conditions were $96{ }^{\circ} \mathrm{C}$ for $5 \mathrm{~min} ; 35$ cycles consisting of $96^{\circ} \mathrm{C}$ for $1 \mathrm{~min}, 55^{\circ} \mathrm{C}$ for $3 \mathrm{~min}$, and $72^{\circ} \mathrm{C}$ for $1 \mathrm{~min}$; and $72{ }^{\circ} \mathrm{C}$ for $7 \mathrm{~min}$. The PCR products were subjected to gel electrophoresis in $1.5 \%$ agarose gel, followed by ethidium bromide staining. The PCR product was sequenced (Macrogen). Sequence assembly was performed with DNA Baser software. Similarity searches with sequences were performed by online BLAST analysis. For phylogenetic analysis, sequences were aligned by using the ClustalW software.

Measurement of Exopolysaccharide (EPS). The measurement of exopolysaccharide (EPS) was conducted as described by Jeong et al. (2008). A single colony of each Xoo strain was inoculated in $40 \mathrm{ml}$ of NB medium and incubated for $72 \mathrm{~h}$ at $28{ }^{\circ} \mathrm{C}$ with agitation. The optical density of the bacterial cultures was adjusted to 1.0 at $600 \mathrm{~nm}$ with NB. The culture supernatants were transferred into new 50-ml tubes and supplemented with $1.0 \%$ potassium chloride $(\mathrm{w} / \mathrm{v}$; final concentration). Two volumes of absolute ethanol were added to each solution, and the tubes were placed at $-20^{\circ} \mathrm{C}$ overnight. The precipitated crude EPS was collected by centrifugation for $30 \mathrm{~min}$ at $83,000 \times \mathrm{g}$. The EPS pellets were dried at $55^{\circ} \mathrm{C}$ for $12 \mathrm{~h}$ and the dry weight of each was measured.

Cellulase Assay. Cellulase activities were assayed as described (Jeong et al. 2008). Xoo strains were cultured in NB medium for $72 \mathrm{~h}$, after which the optical density of the cultures was adjusted to 1.0 at $600 \mathrm{~nm}$ with NB. Thirty microliters of culture supernatant were placed in a hole in the assay agar medium, which contained $0.1 \%$ carboxymethyl cellulose, $50 \mathrm{mM}$ sodium phosphate ( $\mathrm{pH} 7.0$ ), $0.8 \%$ agarose, and $0.02 \%$ sodium azide, and the plate was incubated for $20 \mathrm{~h}$ at $28^{\circ} \mathrm{C}$. The incubated plates were stained with $0.1 \%$ Congo Red for $10 \mathrm{~min}$ and then washed several times with $1 \mathrm{M} \mathrm{NaCl}$. After washing, the cellulase activity was determined by measuring the diameter of the clear zone around the hole.

Pathogenicity and In Planta Assays. The Xoo strains were grown on NB medium for 2 days at $28^{\circ} \mathrm{C}$. The bacterial cells were resuspended in sterilized water at an optical density of $600 \mathrm{~nm}$ (OD 600) (about $10^{-8} \mathrm{cfu}$ $\mathrm{ml}^{-1}$ ). Bacterial blight inoculation was carried out on 6week-old on resistance rice varieties IRBB7 and Code and susceptible rice varieties IR24 and Kencana Bali using the leaf-clipping method (Kaufmann 1973). Experiments were conducted under greenhouse conditions. For pathogenicity assay, the lesion length was measured in 7, 14 and 21 days after inoculation with 10 leaves for each strain. In planta assay was carried out on susceptible rice variety IR24. It determined Xoo strains multiplication in planta at six time points after infection by leaf clipping on 3, 6, 9,12, 15 and 18 days after inoculation. The in planta was assayed as described by $\mathrm{Hu}$ et al. (2007). The leaf pieces were then ground in $10 \mathrm{mM} \mathrm{MgCl} 2$. The leaf homogenate was diluted in $10 \mathrm{mM} \mathrm{MgCl}_{2}$ solution. Serial dilutions were made and spread onto PSA agar plates. The plates were incubated at $28{ }^{\circ} \mathrm{C}$ until the number of colony-forming units (cfu) per leaf was counted. 


\section{RESULTS}

Growth Curve of Xoo. Population growth is studied by analyzing the growth curve of a microbial culture. The bacterial growth can be plotted as the logarithm of the number of viable cells versus the incubation time. The resulting curve has four distinct phases. The cell density of Xоo isolates increased from 0.1 to 2.7 (OD600nm) during $48 \mathrm{~h}$ of growth at $28{ }^{\circ} \mathrm{C}$ (Fig 1). The growth cell started at the early exponential until $18 \mathrm{~h}$ and reached its maximum at the early stationary phase on $24 \mathrm{~h}$ then remained stable until $48 \mathrm{~h}$ during stationary phase. Xoo1122 Isolate showed increasing in its growth rate on exponential phase (18-24 h) however Xoo7624 growing slow compare to other isolates.
Identification of Xoo using $16 \mathrm{~S}$ rRNA and Phylogenetic Analysis. The partial 16S rRNA gene sequences (1490 bp) of all strains were determined. Then, the sequences were compared with related bacteria in GenBank and sequence similarities were determined using the BLAST program. The result confirmed that all isolates showed high homology (99-100\%) to Xanthomonas oryzae pv. oryzae PXO99 ${ }^{\mathrm{A}}$ (Table 2). The Clustalw analysis of the 16S rRNA gene sequences revealed three groups. The first group containing one isolate, Xoo93229, the second group containing. Xoo1110, Xoo1122, Xoo1130, Xoo7624 and Xoo8024 as the same cluster with PXO99 ${ }^{\mathrm{A}}$, and the third group Xoo KACC10331 and MAFF311018 were clustered together (Fig 2).

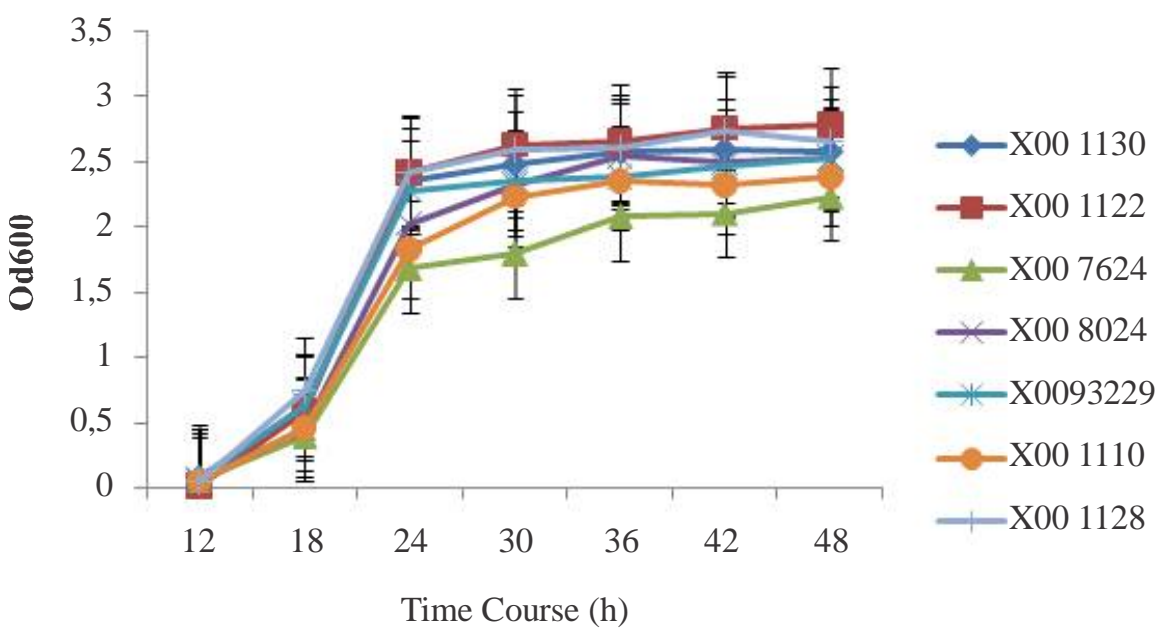

Fig 1 Optical density at $600 \mathrm{~nm}$ of seven Indonesian Xoo Strains.

Table 1 Bacterial strains used in this study

\begin{tabular}{llll}
\hline Strain & Collection site & Cultivar source & Source \\
\hline Xoo93229 & Harjobinangun, Yogyakarta & Cisadane & ICABIOGRAD \\
Xoo7624 & Bogor,West Java & Local Variety & ICABIOGRAD \\
Xoo8024 & Cianjur, West Java & Local variety & ICABIOGRAD \\
Xoo11-010 & Cianjur West Java & Ciherang & ICABIOGRAD \\
Xoo11-022 & Maninjau, West Sumatera & Kuriak Putiah & ICABIOGRAD \\
Xoo11-028 & Maninjau, West Sumatera & Kuriak Putiah & ICABIOGRAD \\
Xoo11-030 & Maninjau, West Sumatera & Kuriak Putiah & ICABIOGRAD \\
\hline
\end{tabular}


Table 2 Identity of Indonesian Xanthomonas oryzae pv oryzae isolates

\begin{tabular}{|c|c|c|c|}
\hline Isolate & Species & Identiity (\%) & Accession Number \\
\hline Xoo93229 & $\begin{array}{l}\text { Xanthomonas oryzae pv. oryzae } \\
\text { PX099 }\end{array}$ & 100 & $\underline{\mathrm{CP} 000967.1}$ \\
\hline Xoo7624 & $\begin{array}{l}\text { Xanthomonas oryzae pv. oryzae } \\
\text { PXO99 }\end{array}$ & 99 & $\underline{\mathrm{CP} 000967.1}$ \\
\hline Xoo8024 & $\begin{array}{l}\text { Xanthomonas oryzae pv. oryzae } \\
\text { PXO99 }\end{array}$ & 100 & $\underline{\mathrm{CP} 000967.1}$ \\
\hline Xoo11-010 & $\begin{array}{l}\text { Xanthomonas oryzae pv. oryzae } \\
\text { PXO99 }\end{array}$ & 99 & CP000967.1 \\
\hline Xoo11-022 & $\begin{array}{l}\text { Xanthomonas oryzae pv. oryzae } \\
\text { PXO99 }\end{array}$ & 100 & $\underline{\mathrm{CP} 000967.1}$ \\
\hline Xoo11-030 & $\begin{array}{l}\text { Xanthomonas oryzae pv. oryzae } \\
\text { PXO99 }\end{array}$ & 99 & CP000967.1 \\
\hline
\end{tabular}

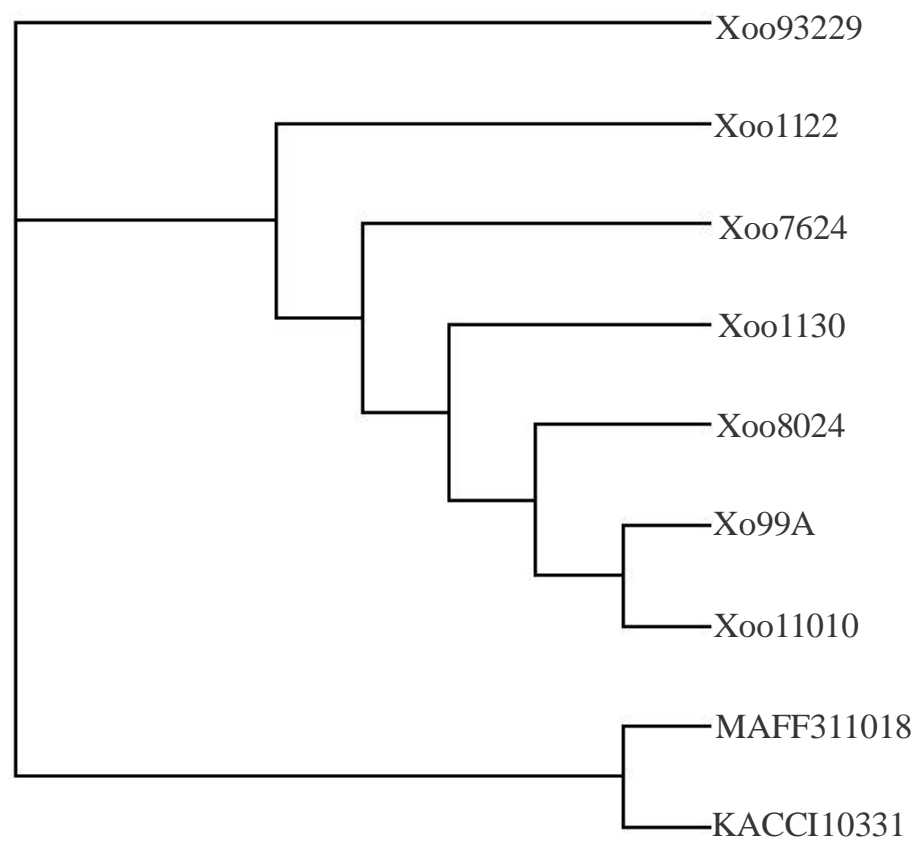

Fig 2 ClustalW analysis of 16S rRNA sequence of Indonesian Xoo Isolates Xoo93229, Xoo7624, Xoo8024, Xoo1110, Xoo1122, and Xoo1130 compared with PXO99A (CP000967), MAFF311018 (AP008229), and KACC10331 (Ae013598).

Measurement of Exopolysaccharide (EPS). The seven tested Xoo colonies produced EPS with different yield of production. Isolate Xoo1130, Xoo1122 and Xoo8024 giving more production of dry weight up to $80 \mathrm{mg}$ however Xoo1110, Xoo7624, Xoo1128 and Xoo93229 showed less production around $40-50 \mathrm{mg}$ (Fig 3).
Cellulase Activities. Cellulase produced by the tested Xoo on medium agar plates showed the clear zones around the wells refer to cellulase activities was measured (Fig 4). All Xoo isolates revealed similar cellulase activity $(17-18 \mathrm{~mm})$ except for strain Xoo8024 (12 mm). 


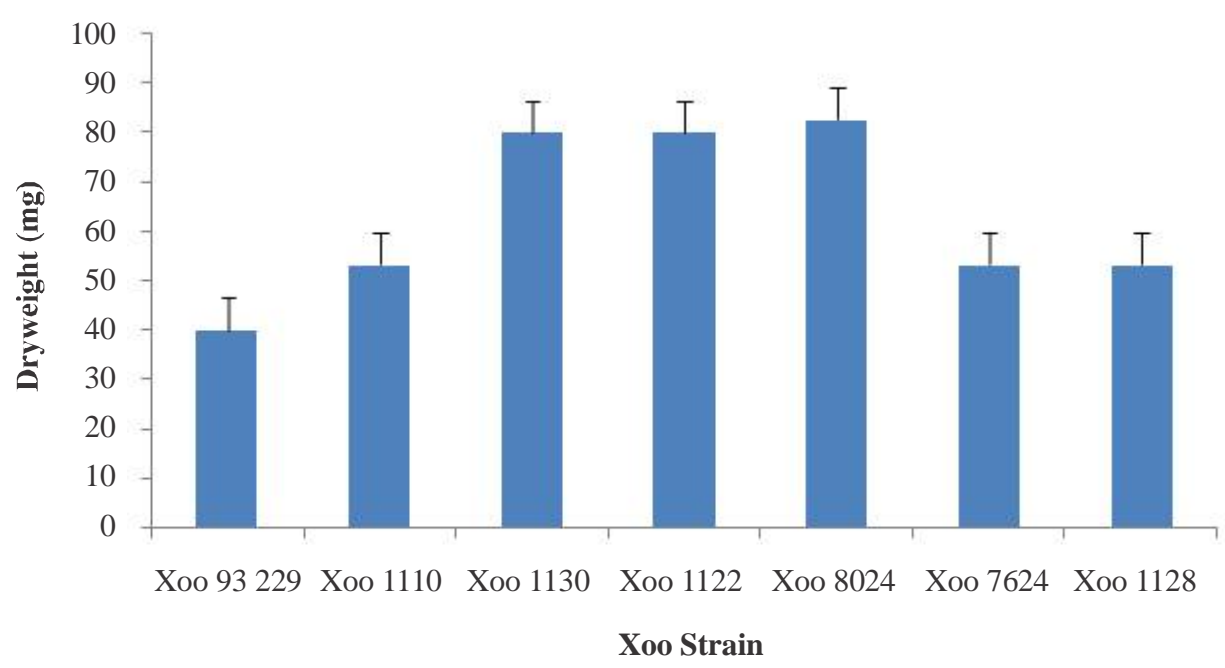

Fig 3 EPS dry weights of seven Indonesian Xoo Strain.
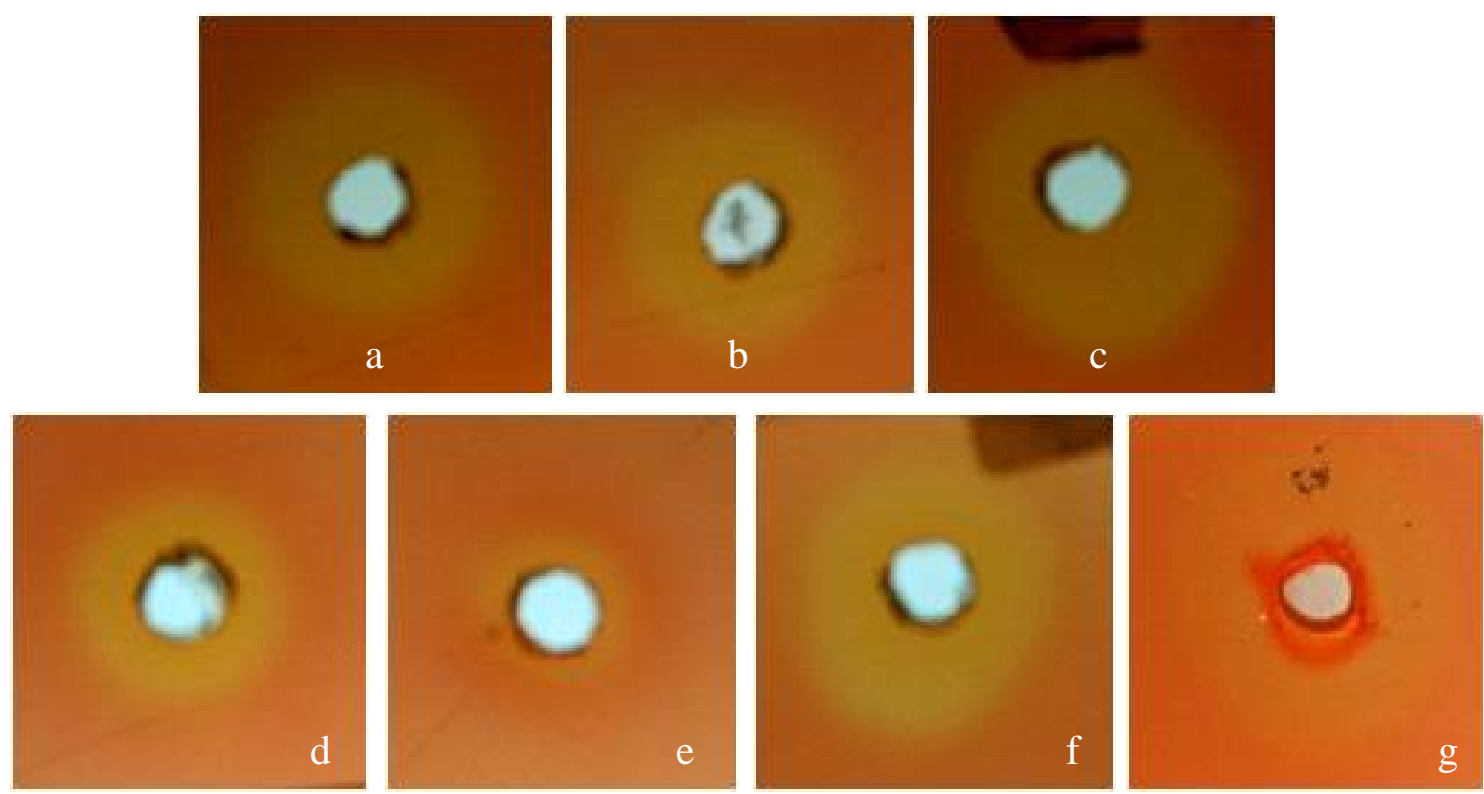

Fig 4 Cellulase produced by the seven Xanthomonas oryzae pv. oryzae on medium agar plates. The clear zones around the wells refer to cellulase activities of Xoo strain (a) Xoo1130, (b) Xoo93229, (c) Xoo110, (d) Xoo1122, (e) Xoo8024, (f) Xoo7624, and (g)Xoo1128.

Pathogenicity Assay. All tested strains caused leaf blight on the surface of rice cultivar IR 24 on 5 days after inoculation. The development of bacterial leaf blight symptoms in rice plants inoculated with Xoo strains observed on lesions leaf of resistant cv. IRBB7 and Code and susceptible cv. IR24 and Kencana Bali on $21 \mathrm{~d}$ post inoculation. Symptoms of BLB appeared on leaves as pale-green to grey-green water-soaked streaks near the leaf tip and margin. These lesions coalesced and became yellowish-white with wavy edges. On leaf sheath of susceptible cultivars, the affected leaves will turn yellow, roll up and wilt rapidly and systemic infection that produces tannishgrey to white lesions along the vein under greenhouse inoculation (Fig 5).

Differences in virulence among the Xоo strains were quantified according to the lesion length of the necrotic area. Xoo93229, Xoo1122, Xoo1128, Xoo1130, Xoo1110 and Xoo8024 strains were shown to cause symptoms at day 7 after inoculation. It also showed the development of disease and increased virulence to susceptible rice cultivar IR24 at $21 \mathrm{~d}$ post inoculation. The average lesion length was $30,31,32,32,27$, and $26 \mathrm{~cm}$, respectively. Strain Xoo7624 showed the lowest lesion length at day 7 post inoculation and displayed the same pattern of lesion length until $21 \mathrm{~d}$ post inoculation (Fig 6). 


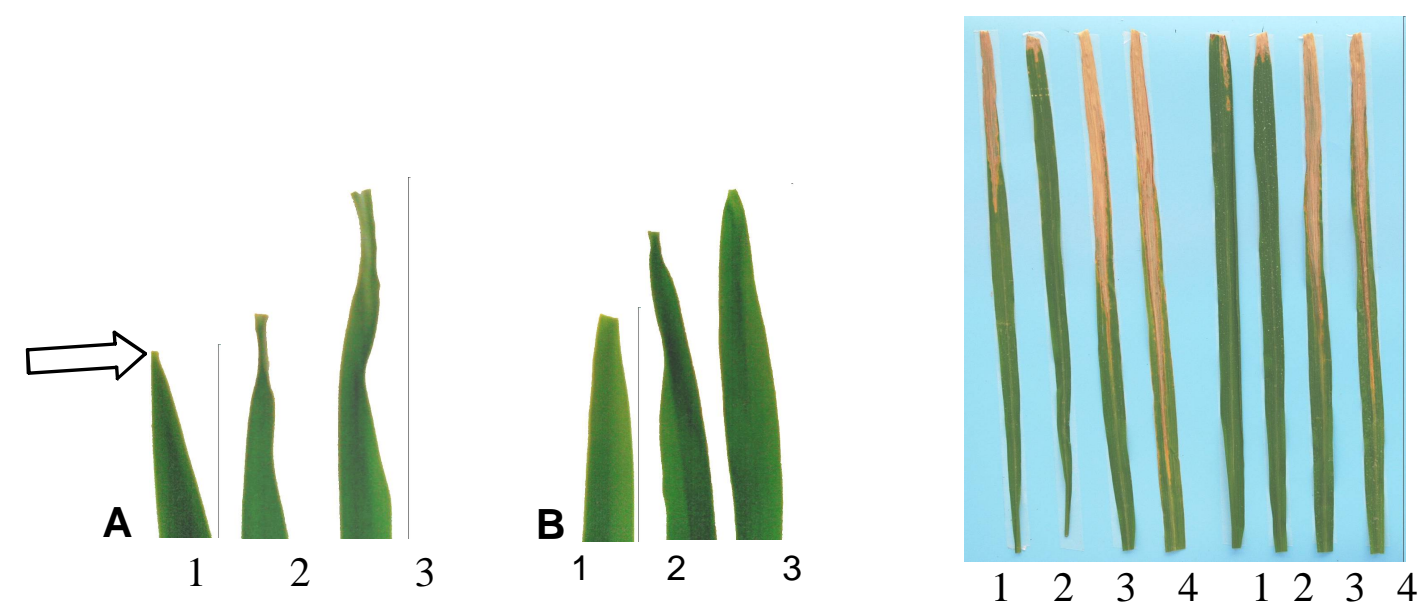

Fig 5 Leaf phenotype of IRBB7 and IR24 as an example showing increased susceptibility to pathogen strain (A) Xoo93229 and (B) Xoo1122. Leaf 1) IRBB7, leaf 2) and 3) IR24. Leaves were photographed 5 days after inoculation. Arrow indicates position of clip-inoculation of the leaf tips. (C) Lesions leaves of 21 days after inoculated with Xoo93229 (left) and Xoo1122 (right). Resistant cultivar: Leaf 1) IRBB7 2). Code and Susceptible cultivar: 3) IR24, and 4) Kencana Bali.

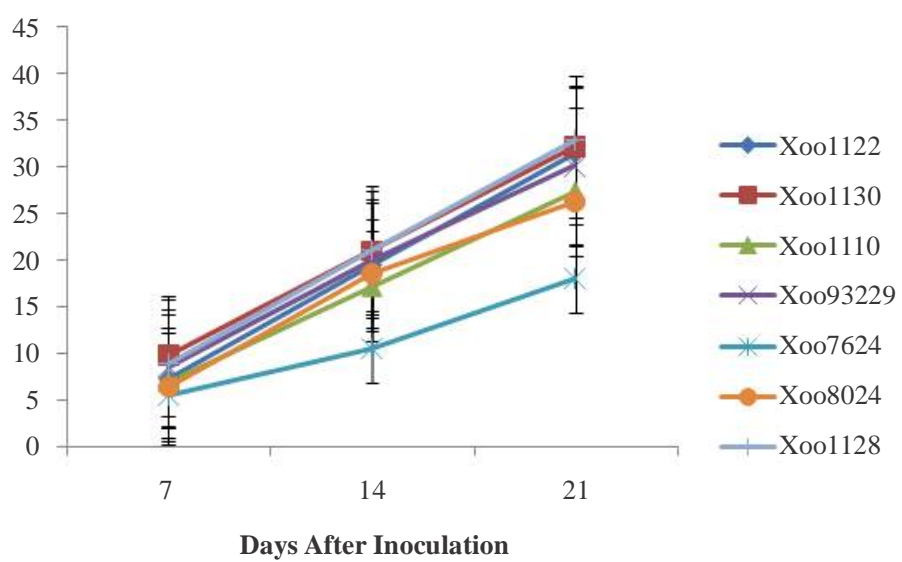

Fig 6 Pathogenicity assay of Xoo strains on the susceptible rice cultivar IR24. Length of lesions was measured in 7, 14, and 21 DAI with 10 leaves for each strain.

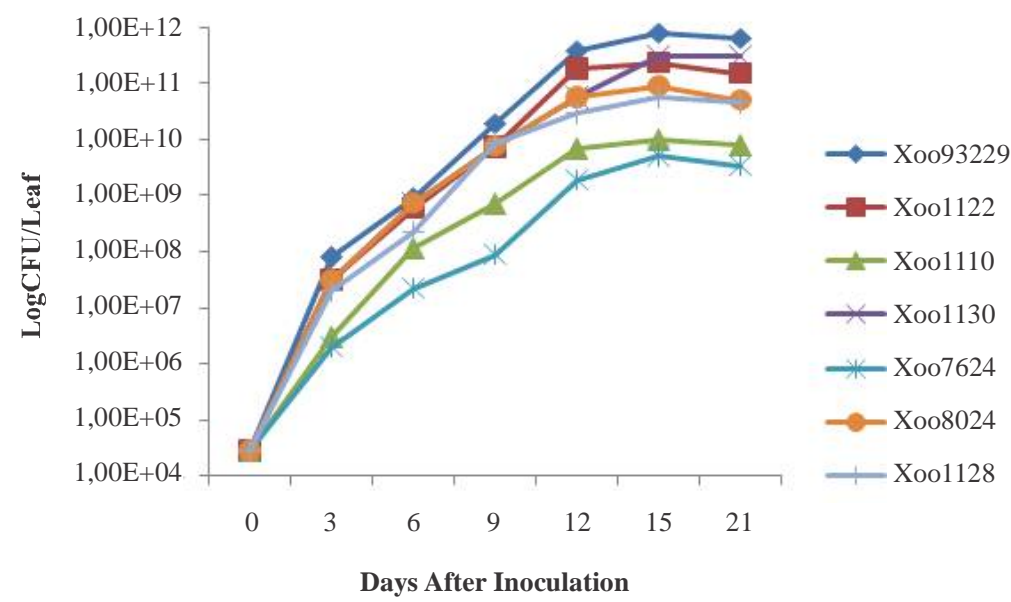

Fig 7 Growth curve of Xoo isolates on rice leaves after inoculation. Mean CFU per leaf was calculated from two independent experiments with three leaves for each strain. 
In Planta Assay. Similar amounts of bacteria $\left(2.8 \times 10^{4} \mathrm{cfu}\right)$ were inoculated on rice by leaf clipping. The Xoo strains multiplied in planta at six time points after infection. Initially, the distinct difference was observed in 3 days after inoculation (DAI) however Xoo1110 and Xoo7624 strain were less in population size $\left(3 \times 10^{6}\right.$ and $2 \times 10^{6}$, respectively). Xoo93229, Xoo1122, Xoo1128 and Xo1130 strain multiplied continued increasing until it reached a maximal population in $10^{11} \mathrm{cfu}$ and Xoo1110 and Xoo7624 strain reached a maximal population in $10^{\circ} \mathrm{cfu}$ within 15 days after inoculation (Fig 7).

\section{DISCUSSION}

The identification of 16 rRNA sequence, characterization of its growth curve and the important virulence factors such as cellulase and extracellular polysaccharide (EPS), pathogenicity assay and in planta assay have been examines in this study using seven Indonesian Xoo isolates. The amounts of EPS and cellulase produced were varying depending on the Xoo strain.

The identification of 16 rRNA gene sequence was used to confirm the identity of strains. The 16S rRNA gene is most typically used for classification of bacteria. In this study, the 16S rRNA gene sequenced of all Xoo isolates used confirmed high homology to Xanthomonas oryzae pv. oryzae PXO99 ${ }^{\mathrm{A}}$ (Salzberg et al. 2008). A dendrogram depicting the estimated phylogenetic relationship was based on comparisons of the available 16s rRNA sequence data for the Xanthomonas oryzae pv oryzae. Indonesian Xoo isolates was clustered as the same cluster with $\mathrm{PXO} 9^{\mathrm{A}}$ (Salzberg et al. 2008) however the isolate Xoo93229 was in different cluster. Hauben et al. (1997) reported that a very small degree of divergence of $16 \mathrm{~S}$ rRNA gene sequences among the Xanthomonas. Lang et al. (2010) reported the high degree of diversity of Xanthomonas isolates within and between countries. In this study, the third cluster consisted of Korean strain KACC10331 (Lee et al. 2005) and the Japanese strain MAFF311018 (Ochiai et al. 2005). It was similar with Salzberg et al. (2008) which used the phylogenetic relationships among $\mathrm{PXO}^{\mathrm{A}}$ and the complete genome of the genomes of MAFF311018, and KACC10331 generated a cladogram where MAFF311018 and KACC10331 was grouped together.
The Xoo1130, Xoo1122 and Xoo8024 isolates produced high EPS compare to other isolates. Based on their colony morphology, these three isolates were mucoid and shiny when compared with the other isolates (data not shown). This phenotype results from the production of copious amounts of the extracellular polysaccharide (EPS), known as xanthan gum. Thein and Prathuangwong (2010) reported that colonies of mutants were smaller when compared with the wild type that resulted from less production of EPS. In this study, we used Jeong et al. (2008) method which the NB medium does not contain sucrose, results in a more consistent optical density for Xoo, and was used for EPS assays. He et al. (2006) mentioned that high concentrations of sucrose in the medium have been reported to result in high background in assays of some extracellular enzyme activities. However it should be noted that Lan et al. (2007) observed in long-term storage and culture will lead to spontaneous loss of virulence and associated with reduction of EPS production. Partially purified EPS preparations have been found to induce rice leaf wilting. This may be due to cell membrane leakage caused by EPS (Yang and White 2004).

The diameter of the zone of clearance indicates the ability of the bacteria to hydrolyze cellulase. The capacity of the bacterial isolates to degrade cellulase was indirectly determined using the degradation of carboxymethyl-cellulose (CMC), indicating endoglucolytic activity (Soares et al. 2012). In this study, all of the Xoo tested isolates giving similar cellulase activity except for isolate Xoo8024. However the variation of cellulase activity using plate assay method was not related with the virulence ability. $\mathrm{Hu}$ et al. (2007) reported that cellulase plate assay method failed to discriminate the difference of enzyme activity between mutants and wild type also mentioned by Jeong et al. (2008) that the cellulase activities of the rpf mutants and the complementation strains were similar to those of the wild-type.

Efficient methods for recovering bacterial cells directly from plant tissues permit analyses of in vivo expression in plant-pathogen interactions (Mehta 2003) and may help in the early detection of genes involved in pathogenicity (Thwaites et al 2004). Hu et al. (2007) showed that the expression of the gene can only be detected when Xoo grows in planta but cannot be detected when it grows on PSA agar. In this study, the difference of population size and the increasing of multiplication related with the ability to colonize rice 
seedlings have associated with the virulence ability. The pathogenicity assay among the Xoo isolate showed severely increased virulence to susceptible rice cultivar IR24 except for Xoo7624. However it assumed that our result comes from wild type compare to mutant type generated by study of Feng et al. (2009) reported that the xrvA mutant GXN1280 and the xrvA overexpression strain GXO3098 showed a significant reduction in lesion length compared to the wild-type strain but the bacterial populations of these mutants in rice leaves were not significantly different from that of the wild-type.

In this study, isolate Xoo1130 and Xoo1122 revealed high yield of EPS, cellulase activity, virulence, and increasing population size. In contrary with Xoo7624 revealed low yield of EPS, less virulence, and low number of population size but high cellulase activity. Xoo93229 revealed high cellulase activity, more virulence, and increasing population size but low yield of EPS production. Xoo8024 with high yield production of EPS, more virulence and increasing population size was low in cellulase activity. Initially it was presumed that all the tested isolates will have association between the virulence factor and pathogenicity. Regarding phenotypic characterization, recent molecular characterization of Xoo, the availability of genome sequence for rice and Xoo may facilitate our research for identification of many new pathogen-associated molecular patterns (PAMPs) and avirulence and virulence effectors (Liu et al. 2014).

\section{ACKNOWLEDGMENT}

This work was financially supported by Indonesian Toray Science Foundation Science and Technology Research Grant (ITSF-STRG). We thank to Mahrup and Milannisa Dwitaharyani for technical support.

\section{REFERENCES}

Buttner D, He SY. 2009. Type III protein secretion in plant pathogenic bacteria. Plant Physiol. 150:1656-1664. doi:10.1104/pp.109.139089.

Chao SY, Tomii K, Watanabe, Tsai Y. 2008. Diversity of lactic acid bacteria in fermented brines used to make stinky tofu. Int J Food Microbial. 123:134-141. doi: 10.1016/j.ijfoodmicro.2007.12.010.

Feng JX. Song ZZ, Duan CJ, Zhao S, Wu YQ, Wang CW, Dow JM, Tang JL. 2009. The xrvA gene of Xanthomonas oryzae pv. oryzae, encoding an H-NSlike protein, regulates virulence in rice. Microbiology.
(155):3033-3044.

George MLC, Bustamam M, Cruz WT, Leach JE, Nelson RJ. 1997. Movement of Xanthomonas oryzae pv oryzae in southeast Asia detected using PCR-based DNA finger printing. Phytopathology, 87:302-309. doi.org/10.1094/PHYTO.1997.87.3.302

Hauben L, Vauterin L, Swings J, Moore ERB. 1997. Comparison of 16s Ribosomal DNA Sequences of all Xanthomonas Species. Int J syst Bacterial 2: 328-335. doi: 10.1099/00207713-47-2-328.

He YW, Wang C, Zhou L, Song H, Dow JM, Zhang LH. 2006. Dual signaling functions of the hybrid sensor kinase RpfC of Xanthomonas campestris involved either phosphorelay or receiver domain-protein interaction. J. Biol.Chem. 281:33414-33421.doi: 10.1074/jbc.M606571-200.

Hu JW, Qian, He C. 2007. The Xanthomonas oryzae pv.oryzae eglXoB endoglucanase gene is required for virulence to rice. FEMS Microbiol Lett. (269)273-279. doi:10.1111/j.1574-6968.2007.00638.

Jeong KS, Lee SE, Han JW, Yang SU, Lee BM, Noh TH, Cha JS. 2008. Virulence reduction and differing regulation of virulence genes in rpf mutants of Xanthomonas oryzae pv. oryzae. Plant Pathol. J. 24(2): 143-151.

Kauffman HE, Reddy APK, Hsieh SPY, Merca SD. 1973. An improved technique for evaluating resistance of rice varieties to Xanthomonas oryzae pv. oryzae. Plant Diseases. Rep.57: 537-541.

.Lan L, Deng X, Xiao Y, Zhou JM, Tang X. 2007. Mutation of Lon Protease Differentially Affects the Expression of Pseudomonas syringae Type III Secretion System Genes in Rich and Minimal Media and Reduces Pathogenicity. Mol Plant Microbe Interact. 20 (6):682696. doi.org/10.1094/MPMI-20-6-0682.

Lang JM, Hamilton JP, Diaz MGQ, Van Sluys MA, Burgos MRG, Vera Cruz CM, Buell CR, Tisserat NA, Leach JE. 2010. Genomics-based diagnostic marker development for Xanthomonas oryzae pv. oryzae and X. oryzae pv. oryzicola. Plant Dis. 94:311-319. doi:10.1094 / PDIS94-3-0311.

Lee BM, Park YJ, Park DS, Kang HW, Kim JG, Song ES, Park IC, Yoon UH, Hahn JH, other authors 2005. The genome sequence of Xanthomonas oryzae pathovar oryzae KACC10331, the bacterial blight pathogen of rice. Nucleic Acids Res 33(2): 577-586. doi: 10.1093/nar/gki206

Liu DO, Ronald PC, Bogdanove AJ. 2006. Xanthomonas oryzae pathovars: model pathogens of a model crop. Mol Plant Pathol. 7(5):303-24. doi: 10.1111/j.13643703.2006.00344.

Liu W, Jinling L, Lindsay T, Jan EL and Guo LW. 2014. Novel insights into rice innate immunity against bacterial and fungal pathogens. Annu. Rev. 
Phytopathol. 52:213-41 doi: 10.1146/annurev-phyto102313-045926

Mansfield J., Stephane G, Shimpei M, Vitaly C, Malinee S, Pamela R, Max D, Valérie V, Steven VB, Marcos AM, Ian T, George S, Gary DF. 2012. Top 10 plant pathogenic bacteria in molecular plant pathology. Molecular Plant Pathology 13(6):614-629. doi: 10.1111/J.1364-3703.2012.00804.

Mehta A, Rosato Y. 2003. A simple method for in vivo expression studies of Xanthomonas axonopodis pv. citri. Curr Microbiol 47:400-40.

Mew TW, Alvarez AM, Leach JE, Swings J. 1993. Focus on bacterial blight of rice. Plant Dis 77:5-12.

Nozue K, Park CJ, Ronald PC. 2011. Quantitative measurements of Xanthomonas oryzae pv. oryzae distribution in rice using fluorescent-labelling. J. Plant Biol. 54(4):269-274. doi:10.1007/s12374-011-9164-9.

Ochiai H, Inoue Y, Takeya M, Sasaki A, Kaku H. 2005. Genome sequence of Xanthomonas oryzae pv. oryzae suggests contribution of large numbers of effector genes and insertion sequences to its race diversity. JARQ 39(4):275-287.

Ou SH. 1985. Rice Diseases. Kew, UK: Commonwealth Agricultural Bureaux.

Salzberg SL, Sommer DD, Schatz MC, Phillippy AM, Rabinowicz PD, Tsuge S, Furutani A, Ochiai H, Delcher AL, other authors. 2008. Genome sequence and rapid evolution of the rice pathogen Xanthomonas oryzae pv. oryzae PXO99A. BMC Genomics (9) 204:116. doi:10.1186/1471-2164-9-204.

Soares FL, Itamar SM, Armando CFD, Fernando DA. 2012. Cellulolytic bacteria from soils in harsh environments. World J Microbiol Biotechnol. 28:2195-2203. doi 10.1007/s11274-012-1025-2.
Subramoni S, Jha G, Sonti RV. 2006. Plant-Associated Bacteria: Virulence Functions of Xanthomonads. 535571. Springer, The Netherlands.

Temuujin, Jae-Won Kim, Jong-Kun Kim, Byoung-Moo Lee, Hee-Wan Kang. 2011. Identification of novel pathogenicity-related cellulase genes in Xanthomonas oryzae pv. oryzae. Physiol Mol Plant Pathol 76:152157. doi:10.1016/j.pmpp.2011.08.004.

Thein A. and S. Prathuangwong. 2010. Novel Strains of Xanthomonas oryzae pv. oryzae UV Mutated Induce Systemic Resistance in Rice against Bacterial Leaf Blight Disease. Kasetsart J Nat Sci. 44: 1026-1043.

Thwaites R, Spanu PD, Panopoulos NJ, Stevens C, Mansfield JW. 2004. Transcriptional Regulation of Components of the Type III Secretion System and Effectors in Pseudomonas syringae pv. phaseolicola. Mol Plant Microbe Interact 17:1250-1258. doi:10.1094/MPMI.2004. 17.11.1250.

Verdier V, Lindsay RT, Aaron WH, Rene C, R. Andres C, Clarice LS, Adam JB, Jan EL. 2012. Transcription activator-like (TAL) effectors targeting OsSWEET genes enhance virulence on diverse rice (Oryza sativa) varieties when expressed individually in a TAL effector-deficient strain of Xanthomonas oryzae. New Phytologist. doi: 10.1111/j.1469-8137.2012.04367.

White FF Potnis N. Jones JB. and Kloebnik R. 2009. The type III effectors of Xanthomonas. Mol Plant Pathol. 10: 749-766. doi: 10.1111/J.1364-3703.2009.00590.

Yang B, White F. 2004. Diverse members of the AvrBs3/PthA family of type III effectors are major virulence determinants in bacterial blight disease of rice. Mol Plant Microbe Interact, 17:1192-1200. doi.org/10.1094/MPMI.2004.17.11.1192. 